\title{
A case report of simultaneous PML-IRIS during corticosteroids tapering in a patient with an anti-synthetase syndrome
}

\section{[version 1; peer review: 2 approved, 1 approved with}

\section{reservations]}

\author{
Guillaume Martin-Blondel1-3, David Brassat2-4, Hervé Dumas5, \\ Emmanuelle Uro-Coste 3,6 , Daniel Adoue 3,7 , Hans Lassmann ${ }^{8}$, Michel Clanet $2-4$ \\ ${ }^{1}$ Department of Infectious and Tropical Diseases, Toulouse University Hospital, Toulouse, France \\ ${ }^{2}$ INSERM UMR 1043, Centre de Physiopathologie, Toulouse-Purpan, France \\ 3Université Toulouse III, Toulouse F-31000, France \\ ${ }^{4}$ Department of Neurology, Toulouse University Hospital, Toulouse, France \\ ${ }^{5}$ Department of Neuroradiology, Toulouse University Hospital, Toulouse, France \\ ${ }^{6}$ Department of Pathology, Toulouse University Hospital, Toulouse, France \\ ${ }^{7}$ Department of Internal Medicine, Toulouse University Hospital, Toulouse, France \\ ${ }^{8}$ Center for Brain Research, Medical University of Vienna, Vienna, Austria
}

V1 First published: 23 Dec 2013, 2:283

https://doi.org/10.12688/f1000research.2-283.v1

Latest published: 23 Dec 2013, 2:283

https://doi.org/10.12688/f1000research.2-283.v1

\section{Abstract}

We report a case of simultaneous progressive multifocal leukoencephalopathy-associated immune reconstitution inflammatory syndrome (PML-IRIS) during corticosteroid tapering in a patient with an anti-synthetase syndrome. We describe the challenges associated with the diagnosis and the management of this emerging inflammatory neurological condition in this immunocompromised patient with a severe rheumatic disease. We highlight that, in the setting of IRIS, the low-level of the JC virus viral load requires a sensitive PCR assay before excluding PML.

Keywords

JC virus, Progressive multifocal leukoencephalopathy, Immune reconstitution inflammatory syndrome, Antisynthetase syndrome, Corticosteroids.

\author{
Open Peer Review \\ Approval Status ? \\ 12 \\ 23 \\ version 1 \\ 23 Dec 2013

$?$
view

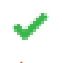 \\ view \\ 1. Gabriele Arendt, University Hospital of \\ Düsseldorf, Düsseldorf, Germany \\ 2. Joseph Berger, University of Kentucky, \\ Lexington, KY, USA \\ 3. Xin Dang, Beth Israel Deaconess Medical \\ Center, Boston, MA, USA \\ Any reports and responses or comments on the \\ article can be found at the end of the article.
}


Corresponding author: Guillaume Martin-Blondel (martin-blondel.g@chu-toulouse.fr)

Competing interests: No competing interests were disclosed.

Grant information: The author(s) declared that no grants were involved in supporting this work.

Copyright: (c) 2013 Martin-Blondel G et al. This is an open access article distributed under the terms of the Creative Commons Attribution License, which permits unrestricted use, distribution, and reproduction in any medium, provided the original work is properly cited. Data associated with the article are available under the terms of the Creative Commons Zero "No rights reserved" data waiver (CC0 1.0 Public domain dedication).

How to cite this article: Martin-Blondel G, Brassat D, Dumas $\mathrm{H}$ et al. A case report of simultaneous PML-IRIS during corticosteroids tapering in a patient with an anti-synthetase syndrome [version 1; peer review: 2 approved, 1 approved with reservations] F1000Research 2013, 2:283 https://doi.org/10.12688/f1000research.2-283.v1

First published: 23 Dec 2013, 2:283 https://doi.org/10.12688/f1000research.2-283.v1 


\section{Introduction}

Progressive multifocal leukoencephalopathy (PML) is a devastating disease due to reactivation of the Polyomavirus JC virus (JCV) in immunocompromised patients ${ }^{1}$. PML has been associated with immune reconstitution inflammatory syndrome (IRIS) during immune recovery of HIV-infected patients treated by antiretroviral therapy, or in non HIV-infected patients after the withdrawal of therapeutic monoclonal antibodies ${ }^{2,3}$. Here we describe a case of simultaneous PML-IRIS during corticosteroids tapering in a patient with an antisynthetase syndrome (ASS).

\section{Case report}

A 62-year-old right-handed French Caucasian woman was diagnosed in October 2007 for an ASS and treated by corticosteroids (methylprednisolone $40 \mathrm{mg} /$ week and prednisolone $20 \mathrm{mg} /$ day) and mycophenolate mofetil (3 g/day). In March 2010 white blood cell count showed profound lymphopenia $\left(486 / \mathrm{mm}^{3}\right.$, normal range 1,500 to $4,000 / \mathrm{mm}^{3}$, Figure 1). Because the ASS was controlled, methylprednisolone was stopped and prednisolone was progressively tapered to $7.5 \mathrm{mg} /$ day. In May 2010 she presented progressive cognitive impairment, followed by a brisk worsening in July 2010 with dizziness and falls. At admission on July $8^{\text {th }} 2010$ neurological

\section{Blood lymphocyte count and immunophenotyping}
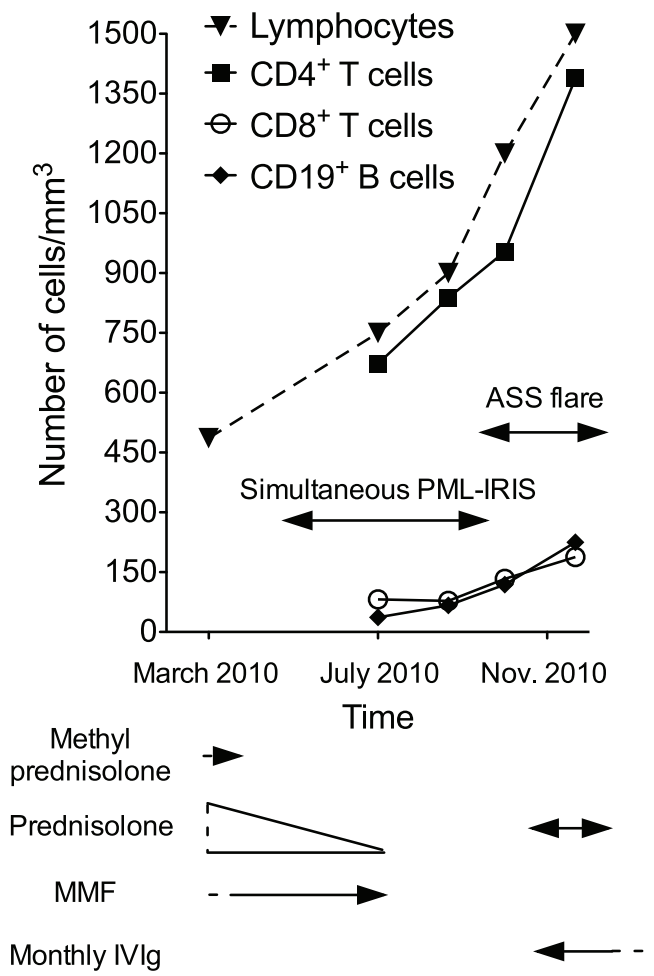

Figure 1. Course of blood lymphocytes according to symptoms and therapy. Arrows underneath the graph represent treatment periods. Single arrow heads represent treatments that were begun or stopped outside of the time period represented on the graph. ASS: Anti-synthetase syndrome; MMF: mycophenolate mofetil. examination revealed mental slowness, attention and memory troubles, and paresis of the left lower limb. Brain axial T2-WI MRI revealed confluent subcortical white matter hyperintensities of the right frontal and parietal region (Figure 2A). Axial T1-WI MRI displayed hypointensities with multiple foci of gadolinium enhancement (Figure 2B). Prednisolone and mycophenolate mofetil were stopped. The differential diagnoses were viral encephalitis, tuberculosis, cerebral lymphoma, paraneoplastic disorder and CNS involvement of a connective tissue disorder. General examination did not demonstrate any activity of the ASS. Blood cell count showed 750 lymphocytes $/ \mathrm{mm}^{3}$ (Figure 1). Cerebrospinal fluid (CSF) examination on day 2 was normal, and in-house PCR (Herpesviridae, enterovirus, JCV, BK virus, Toxoplasma gondii and Mycobacterium tuberculosis), and serologies (HIV, Borrelia and syphilis), were negative, as well as direct staining and cultures for bacteria and fungi. Blood immunophenotyping showed $673 \mathrm{CD}^{+}{ }^{+} \mathrm{T}$ cells $/ \mathrm{mm}^{3}$ (normal range 500-1,500), $82 \mathrm{CD} 8^{+} \mathrm{T}$ cells $/ \mathrm{mm}^{3}$ (normal range 250-950) and $37 \mathrm{CD} 19^{+} \mathrm{B}$ cells $/ \mathrm{mm}^{3}$ (normal range 100-600) (Figure 1). The level of anti-Jo1 antibodies previously detected (Nov 2009, 7.4 AI (normal range 0-0.9) was decreasing (5.9 AI) and a screening for anti-neutrophil cytoplasmic and onconeuronal antibodies was negative. A computed tomography scan showed steady lung interstitial infiltrates, and no evidence for sarcoidosis, tuberculosis or cancer. A stereotactic brain biopsy of the right parietal lobe was performed on July $16^{\text {th }} 2010$. Neuropathological examination showed demyelinated lesions with axonal loss and a severe inflammatory reaction with a vasculitic component and endothelial damage (Figure 2D-E). Perivascular and parenchymal inflammatory infiltrates showed a pronounced $\mathrm{CD}^{+} \mathrm{T}$ cell infiltrate (Figure $2 \mathrm{~F}$ ) composed mostly by $\mathrm{CD} 4^{+} \mathrm{T}$ cells, in association with a few $\mathrm{CD} 8^{+}$macrophages/microglial cells and CD138 ${ }^{+}$plasma cells. Anti-Simian virus 40 (SV40) immunohistochemistry (cross-reacting with the JCV) was positive, and a second aliquot of the CSF taken on day 2, sent to Dr. Major's laboratory at the NIH, was positive for JCV by Real-time TaqMan PCR at a low level $(23 \text { copies } / \mathrm{ml})^{4}$, both firmly establishing the diagnosis of PML. A diagnosis of simultaneous PML-IRIS with vasculitis was made. As in the meantime her neurological status had stabilized, the patient did not receive corticosteroids. When followed up in November 2010, mental slowness and paresis of the left lower limb had completely recovered, and repeated MRI showed improvement of previous lesions. In parallel, blood immunophenotyping showed partial normalization (Figure 1). However, concomitantly she presented with a severe flare of the ASS, with myositis, polyarthritis and active interstitial pneumonitis. A one-week course of oral corticosteroids was initiated together with monthly intravenous polyclonal immunoglobulin therapy (IVIg). By December 2012 the ASS was considered under control with IVIg alone. The patient was fully independent without any neurological abnormalities, while MRI showed sequellar lesions (Figure 2C).

\section{Discussion}

The diagnosis of PML in this immunocompromised patient is firmly established by the detection of JCV DNA in the CSF and of viral proteins on the brain biopsy sample, and by the exclusion of alternative infections or tumors ${ }^{1}$. 

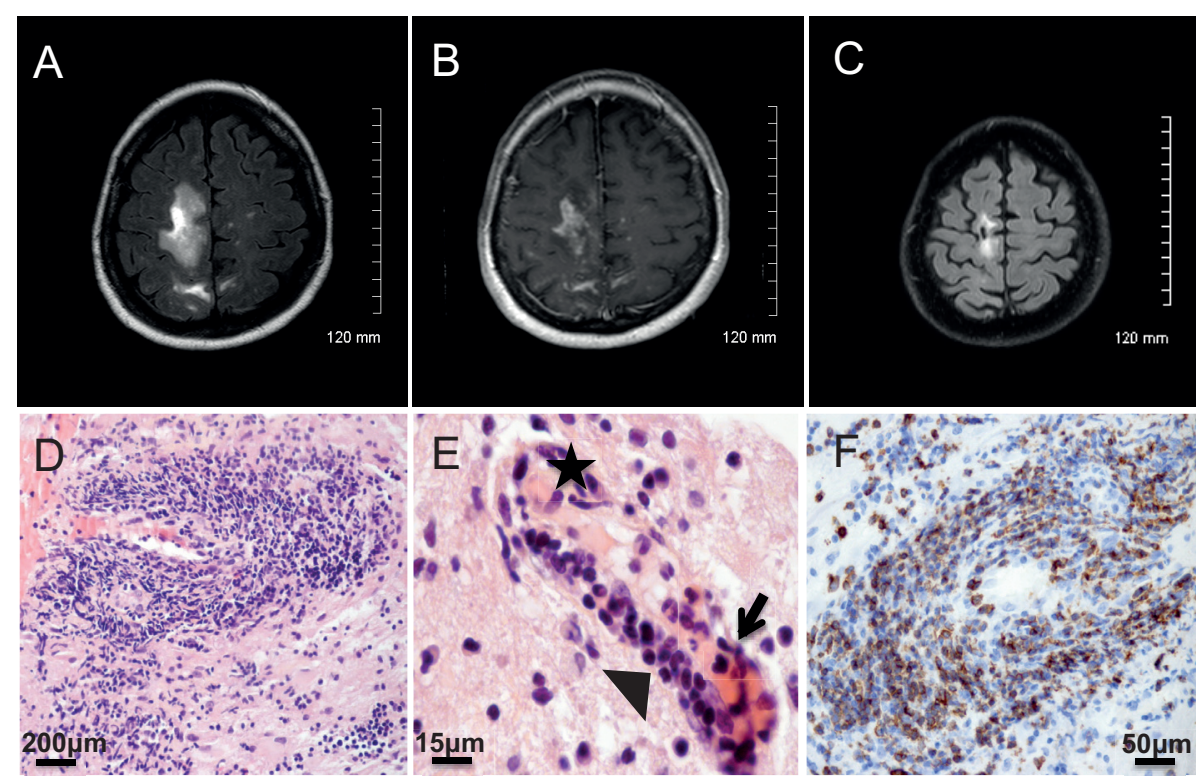

Figure 2. Brain MRI and histopathology. A-B: Brain MRI at the onset of the simultaneous PML-IRIS showing white matter hyperintensities of the right frontal and parietal region ( $\mathrm{A}$, axial T2-WI) with multiple foci of gadolinium enhancement (B, axial T1-WI). C: Brain MRI nine months after the onset of PML-IRIS showing sequellar lesions (axial T2-WI). D-E: Histopathology showing severe perivascular infiltrates $(D, H \& E \times 200$ ) with a vasculitic component $(\mathrm{E}, \mathrm{H} \& \mathrm{E} \times 630$, star: fibrin deposit, arrow: neutrophils and serohematic material, arrowhead: lymphocytes infiltrating vessel wall). F: Immunohistochemistry analysis $(\times 400)$ showing perivascular inflammatory infiltrates positive for CD3 antibody (clone F7.2.38, DAKO).

However, this PML case is associated with very unusual inflammatory features, as attested by contrast enhancement on brain MRI and $\mathrm{T}$ cell infiltrates with a vasculitic component on brain biopsy. Because the level of immunosuppression was recently alleviated in this patient, as suggested by the increase of the blood lymphocyte count at admission, we believe that this patient developed a simultaneous PML-IRIS. The development of neurologic abnormalities due to an unusual inflammatory form of PML in the setting of immune recovery is consistent with the definition of simultaneous IRIS $^{5}$. IRIS results from the restoration of an antimicrobial immune response that causes disproportionate tissue damage in infected organs $^{6}$. In this case, the corticosteroid tapering, by restoring partially immune surveillance, might have unleashed the T-cell mediated immune response underlying PML-IRIS. The subsequent control of the viral replication might explain the low-level of the CSF viral load in this patient, highlighting that a sensitive PCR assay is required to exclude PML in the setting of IRIS.

Brain infiltrates were mainly composed of $\mathrm{CD} 4^{+} \mathrm{T}$ cells, which is another unusual feature of this case. Indeed, a clear dominance of $\mathrm{CD}^{+} \mathrm{T}$ cells in infiltrates has been observed in natalizumabassociated PML-IRIS in patients with multiple sclerosis (MS) ${ }^{7}$, and in PML-IRIS in HIV-infected patients ${ }^{8}$. Nevertheless, a recent case report suggested a central role for $\mathrm{CD}^{+} \mathrm{T}$ cells in natalizumabassociated PML-IRIS in a patient with $\mathrm{MS}^{9}$. The fact that lymphopenia in our patient mainly relies on $\mathrm{CD}^{+} \mathrm{T}$ cells, and not on $\mathrm{CD} 4^{+}$ $\mathrm{T}$ cells, conversely to the situation in HIV-infected patients, might in part explain this phenomenon.
Despite severe neurological deterioration, this PML correlates with favorable outcome without corticosteroid treatment. The inflammatory reaction associated with IRIS is often self-limited and does not seem to alter survival of patients with $\mathrm{PML}^{10}$. A better control of viral replication might also have contributed to this positive outcome. Because corticosteroids have a profound impact on the JCVspecific T-cell response, they should be reserved for life-threatening PML-IRIS ${ }^{11}$. Finally when the ASS relapsed, the IVIg therapy was a suitable way to manage the risks of immunosuppression ${ }^{12}$.

In conclusion, PML-IRIS might occur in patients with rheumatic diseases not receiving therapeutic monoclonal antibodies when immunosuppression is alleviated. PML presentation is unusual in this setting, and diagnosis requires a sensitive PCR assay, and/or brain biopsy.

\section{Consent}

Written informed consent for publication of their clinical details and clinical images was obtained from the patient.

\section{Author contributions}

G. Martin-Blondel: Drafting/revising the manuscript for content, including medical writing for content, Study concept or design, acquisition of data, analysis and interpretation of data, study coordination. D. Brassat: Drafting/revising the manuscript for content, acquisition of data, analysis and interpretation of data. H. Dumas: Revising the manuscript for content, neuroradiological analysis. 
E. Uro-Coste: Revising the manuscript for content, pathological analysis. D. Adoue: Revising the manuscript for content, acquisition of data. H. Lassmann: Revising the manuscript for content, pathological analysis. M. Clanet: Drafting/revising the manuscript for content, acquisition of data, analysis and interpretation of data.

\section{Competing interests}

No competing interests were disclosed.
Grant information

The author(s) declared that no grants were involved in supporting this work.

\section{Acknowledgements}

We thank Dr. Camille Laurent who carried out in part the brain histological analysis, and Dr. Eugene O. Major for performing the JCV PCR assay and for reading the manuscript.
1. Tan CS, Koralnik IJ: Progressive multifocal leukoencephalopathy and other disorders caused by JC virus: clinical features and pathogenesis. Lancet Neurol. 2010; 9(4): 425-37.

PubMed Abstract | Publisher Full Text | Free Full Text

2. Tan IL, McArthur JC, Clifford DB, et al.: Immune reconstitution inflammatory syndrome in natalizumab-associated PML. Neurology. 2011; 77(11): 1061-7. PubMed Abstract | Publisher Full Text | Free Full Text

3. Tan K, Roda R, Ostrow L, et al:: PML-IRIS in patients with HIV infection: clinical manifestations and treatment with steroids. Neurology. 2009; 72(17): 1458-64. PubMed Abstract | Publisher Full Text | Free Full Text

4. Ryschkewitsch C, Jensen P, Hou J, et al:: Comparison of PCR-southern hybridization and quantitative real-time PCR for the detection of JC and BK viral nucleotide sequences in urine and cerebrospinal fluid. $J$ Virol Methods. 2004; 121(2): 217-21.

PubMed Abstract | Publisher Full Text

5. Johnson $\mathrm{T}$, Nath $\mathrm{A}$ : Neurological complications of immune reconstitution in HIV-infected populations. Ann NY Acad Sci. 2010; 1184: 106-20. PubMed Abstract | Publisher Full Text

6. Martin-Blondel G, Delobel P, Blancher A, et al:: Pathogenesis of the immune reconstitution inflammatory syndrome affecting the central nervous system in patients infected with HIV. Brain. 2011; 134(pt 4): 928-46. PubMed Abstract | Publisher Full Text

7. Metz I, Radue EW, Oterino A, et al.: Pathology of immune reconstitution inflammatory syndrome in multiple sclerosis with natalizumab-associated progressive multifocal leukoencephalopathy. Acta Neuropathol. 2012; 123(2): 235-45.

PubMed Abstract | Publisher Full Text | Free Full Text

8. Martin-Blondel G, Bauer J, Cuvinciuc V, et al.: In situ evidence of JC virus control by CD8+ T cells in PML-IRIS during HIV infection. Neurology. 2013; 81(11): 964-970.

PubMed Abstract | Publisher Full Text

9. Aly L, Yousef S, Schippling S, et al:: Central role of JC virus-specific CD4+ lymphocytes in progressive multi-focal leucoencephalopathy-immune reconstitution inflammatory syndrome. Brain. 2011; 134(pt 9): 2687-702. PubMed Abstract | Publisher Full Text

10. Harrison DM, Newsome SD, Skolasky RL, et al.: Immune reconstitution is not a prognostic factor in progressive multifocal leukoencephalopathy. Journal of Neuroimmunology. 2011; 238(1-2): 81-6. PubMed Abstract | Publisher Full Text

11. Antoniol C, Jilek S, Schluep M, et al:: Impairment of JCV-specific T-cell response by corticotherapy: effect on PML-IRIS management?. Neurology. 2012; 79(23): 2258-64.

PubMed Abstract | Publisher Full Text

12. Riminton DS, Hartung HP, Reddel SW: Managing the risks of immunosuppression. Curr Opin Neurol. 2011; 24(3): 217-23. PubMed Abstract | Publisher Full Text 


\section{Open Peer Review}

\section{Current Peer Review Status:}

\section{Version 1}

Reviewer Report 07 March 2014

https://doi.org/10.5256/f1000research.3354.r3911

(C) 2014 Dang $X$. This is an open access peer review report distributed under the terms of the Creative Commons Attribution License, which permits unrestricted use, distribution, and reproduction in any medium, provided the original work is properly cited.

\section{Xin Dang}

Department of Neurology, Beth Israel Deaconess Medical Center, Boston, MA, USA

The presence of JCV genomic DNA in CSF is the key evidence for making a diagnosis of PML. However, from time to time in our research, CSF samples from diagnosed PML patients could be JCV negative in conventional PCR; only the most sensitive real time PCR can detect the extremely low JC viral load in these CSF samples. For this reason, I suspect that some PML patients may be misdiagnosed. The remarkable work of Dr. Martin-Blondel's group will encourage other clinicians to look into a possible PML diagnosis in some neural ataxia cases when occurring in immunosuppressed patients.

I have two suggestions that will improve this work:

1. Based on my own experience, JC viral load may increase to a higher level after the PML lesions become visible. If post PML diagnosis CSF samples are available, the data of the JC viral replication kinetic in this patient will help readers gain a better understanding of how JCV replicates in this PML-IRIS patient.

2. This patient also shows cognitive dysfunction, which I suspect may be the symptom of a newly defined JCV associated cerebellar disease called JCV Granule Cell Neuronopathy (JCVGCN). Unfortunately, the MRI of the cerebellum is not available in this paper and the authors didn't look into the presence of GCN type JCV strains. However this won't hurt the integrity of this paper.

Competing Interests: No competing interests were disclosed.

I confirm that I have read this submission and believe that I have an appropriate level of expertise to confirm that it is of an acceptable scientific standard.

Reviewer Report 03 March 2014

https://doi.org/10.5256/f1000research.3354.r3910 
(C) 2014 Berger J. This is an open access peer review report distributed under the terms of the Creative Commons Attribution License, which permits unrestricted use, distribution, and reproduction in any medium, provided the original work is properly cited.

\section{Joseph Berger}

Department of Neurology, University of Kentucky, Lexington, KY, USA

The authors describe a fascinating patient with ASS and PML-IRIS. The latter appeared to develop concomitant with tapering of corticosteroid therapy. I would suggest the following to improve the manuscript:

1. The focus of the paper should be expanded or modified. The occurrence of PML-IRIS at the time of the initial diagnosis of PML is a well-described phenomenon in patients being treated with natalizumab. In fact, as many as $40 \%$ of the them have IRIS concomitant with their PML. This literature should be cited. More importantly, this appears to be the first case of ASS and PML. There is at least one case report of polymyositis and PML, but I could not find another of ASS and PML and I think that is probably more important than the concomitant appearance of PML and PML-IRIS.

2. The figures should include some histopathological sections to demonstrate the demyelination and the SV40 staining. Were bizarre astrocytes and enlarged oligodendroglial nuclei not observed? If so, it should be described.

3. Does ASS ever occur with vasculitis or brain disease? A discussion of this aspect of the differential diagnosis would be helpful to the reader.

4. The authors reserve comment on the specific clinical features of the rheumatological condition to the very end of their case description. I think it would be more useful to incorporate it earlier in their description. When did it develop, what were the clinical features, etc?

5. Do the authors think that the mycophenolate mofetil contributed to the PML? After all, it carries a black box warning in the U.S. for PML.

6. Change the wording from "mainly relies on CD8" to "mainly characterized by CD8" or something similar.

7. This patient had resolution of the IRIS in the absence of corticosteroid treatment. This is another important point as the neurological community has widely embraced employment of steroids at the outset of the disorder. A discussion of this dilemma can be found in Berger, JR (2009).

Competing Interests: No competing interests were disclosed.

I confirm that I have read this submission and believe that I have an appropriate level of expertise to confirm that it is of an acceptable scientific standard, however I have significant reservations, as outlined above. 
Reviewer Report 10 February 2014

https://doi.org/10.5256/f1000research.3354.r3404

(c) 2014 Arendt G. This is an open access peer review report distributed under the terms of the Creative Commons Attribution License, which permits unrestricted use, distribution, and reproduction in any medium, provided the original work is properly cited.

\section{Gabriele Arendt}

Department of Neurology, University Hospital of Düsseldorf, Düsseldorf, Germany

The authors present an article on a patient with an antisynthetase syndrome developing progressive multifocal leucoencephalopathy = PML-IRIS under cortisone tapering. The case is interesting, well presented and important, because it shows that IRIS-PML might occur also when a relatively mild immunosuppression is reduced.

Competing Interests: No competing interests were disclosed.

I confirm that I have read this submission and believe that I have an appropriate level of expertise to confirm that it is of an acceptable scientific standard.

The benefits of publishing with F1000Research:

- Your article is published within days, with no editorial bias

- You can publish traditional articles, null/negative results, case reports, data notes and more

- The peer review process is transparent and collaborative

- Your article is indexed in PubMed after passing peer review

- Dedicated customer support at every stage

For pre-submission enquiries, contact research@f1000.com 